\title{
ОСОБЛИВОСТІ ЕНЕРГОЗАБЕЗПЕЧЕННЯ М’ЯЗОВОЇ ОБОЛОНКИ КЛУБОВОЇ КИШКИ ПРИ РЕЗЕКЦІЯХ РІЗНИХ ОБ’ЄМІВ ПЕЧІНКИ
}

Вступ. Видалення великих об'ємів печінки може супроводжуватися виникненням пострезекційної портальної гіпертензії. Остання призводить до морфологічної перебудови органів басейну ворітної печінкової вени, ураження їх структур, змін енергетичного забезпечення структур, які при пошкодженнях клубової кишки у названих патологічних умовах досліджено недостатньо.

Мета дослідження - вивчити особливості енергетичного забезпечення м'язової оболонки клубової кишки при резекціях різних об'ємів паренхіми печінки.

Методи дослідження. Дослідження проведено на 45 білих щурах-самцях, яких поділили на 3 групи: 1-ша нараховувала 15 інтактних тварин; 2-га - 15 щурів, у яких було видалено 31,5 \% паренхіми печінки; 3-тя - 15 тварин після резекції 58,1 \% паренхіми печінки. Евтаназію експериментальних тварин здійснювали шляхом кровопускання за умов тіопенталового наркозу через місяць від початку досліду. Стан енергетичного забезпечення м'язової оболонки клубової кишки при пострезекційній портальній гіпертензії вивчали, визначаючи в ній рівні АТФ, АДФ та АМФ. Гістологічні препарати клубової кишки фрарбували гематоксилін-еозином, за Ван-Гізон, Маллорі, Вейгертом, толуїдиновим синім. Гістостереометрично визначали товщину м'язової оболонки клубової кишки, відносні об'єми міоцитів, строми, пошкоджених міоцитів, стромально-міоцитарні відношення. Кількісні показники обробляли статистично.

Результати й обговорення. У щурів через місяць після резекції 58,1 \% паренхіми печінки спостерігали розширення ворітної печінкової вени, повнокров'я і розширення брижових вен та видимого венозного русла тонкої і товстої кишок, спленомегалію, асцит. Виявлені зміни свідчили про наявність портальної гіпертензії. Слизова оболонка клубової кишки повнокровна, набрякла, з поодинокими осередками точкових крововиливів. У стінці клубової кишки через місяць після резекції 58,1 \% паренхіми печінки виявили дистрофрію, некробіоз епітеліоцитів, міоцитів, ендотеліоцитів, стромальних структур, інфрільтративні та склеротичні процеси. При видаленні 58,1 \% цього органа відносні об'єми строми збільшилися на 17,5 \%, пошкоджених міоцитів - у 20,5 раза, стромально-міоцитарні відношення - на 21,1\%, що вказувало на значне ураження м'язової оболонки клубової кишки. При виявленому ураженні клубової кишки виражено в м'язовій оболонці знизились рівні АТФ, АДФ, АМФ, що свідчило про суттєве погіршення енергозабезпечення досліджуваної структури.

Висновки. Резекція великих об'ємів паренхіми печінки призводить до розвитку пострезекційної портальної гіпертензії, суттєвого погіршення енергетичного забезпечення м'язової оболонки, пошкоджень структур оболонок та судинного русла клубової кишки. Ступінь зниження енергетичного забезпечення м'язової оболонки залежить від видаленого об'єму паренхіми печінки та вираження пошкоджень структур клубової кишки.

КЛЮЧОВІ СЛОВА: резекція печінки; м’язова оболонка; клубова кишка; енергетичне забезпечення.

ВСТУП. У хірургічних відділеннях лікувальних закладів на сьогодні нерідко виконують резекцію печінки, яку проводять при доброякісних та злоякісних пухлинах, метастазах, травмах печінки, внутрішньопечінковому холангіолітіазі, альвеолярному ехінококозі, трансплантації печінки $[1,2]$. У сучасній медико-біологічній літературі $є$ публікації, в яких відображено результати експериментальних досліджень з вивчення паренхіми печінки при її резекції. Водночас недо(с Л. В.Татарчук, А. Г. Шульгай, М. С. Гнатюк, 2018. статньо досліджено структурні зміни у травному каналі при резекціях різних об'ємів печінки [3, 4]. Вирішення даного питання не тільки має важливе теоретичне значення, але й набуває актуальності у клінічній практиці.

Резекція великих об'ємів паренхіми печінки призводить до пострезекційної портальної гіпертензії, складних загальнобіологічних процесів, які виникають та розвиваються в органах і системах організму при його адаптації до нового рівня життєдіяльності $[1,5,6]$. Необхідно зазна- 
чити, що компенсаторно-адаптаційні процеси, що відбуваються у стінці клубової кишки, її м'язовій оболонці, зміни її енергетичного забезпечення при резекціях різних об'ємів печінки, їх роль у розвитку порушень моторної фрункції до сьогодні досліджено недостатньо, тому ці питання потребують свого вирішення.

Мета дослідження - вивчити особливості енергетичного забезпечення м'язової оболонки клубової кишки при резекціях різних об'ємів паренхіми печінки.

МЕТОДИ ДОСЛІДЖЕННЯ. МорфологічнимИ та біохімічними методами досліджено 45 лабораторних білих статевозрілих щурів-самців, яких поділили на 3 групи: 1-ша (контрольна) нараховувала 15 інтактних експериментальних тварин, які перебували у звичайних умовах віварію; 2-га - 15 щурів, у яких видалили ліву бокову частку (31,5 \% паренхіми печінки); 3-тя - 15 щурів після резекції лівої та правої бокових часток, тобто 58,1 \% паренхіми печінки [3]. Оперативне втручання виконували за умов тіопенталового наркозу з дотриманням правил асептики та антисептики. Через місяць від початку досліду здійснювали евтаназію щурів шляхом кровопускання з використанням тіопенталового наркозу. В м'язовій оболонці клубової кишки визначали вміст АТФ, АДФ, АМФ за W. E. Cohn і C. E. Carter [7]. 3 клубової кишки вирізали шматочки, які фріксували в 10 \% нейтральному розчині фрормаліну і після проведення через етилові спирти зростаючої концентрації поміщали в парафрін. Мікротомні зрізи товщиною 5-7 мкм фрарбували гематоксилін-еозином, за Ван-Гізон, Маллорі, Вейгертом, толуїдиновим синім [8]. Гістологічні мікропрепарати досліджували за допомогою мікроскопів МБД-15 та Люмам-Р8. Гістостереометрично визначали товщину м'язової оболонки клубової кишки (ТМО), відносні об'єми міоцитів у м'язовій оболонці (ВОМ), строми (ВОС), пошкоджених міоцитів (ВОПМ), стромально-міоцитарні відношення (СМВ) [3, 9]. Проводили кореляційний аналіз між вмістом АТФ, АДФ, АМФ у м'язовій оболонці клубової кишки та гістостереометричними показниками з визначенням коесріцієнта (r) кореляції. Силу зв'язку оцінювали за 4-ма ступенями: сильним $(r=0,7-0,9)$, значним $(r=0,5-0,7)$, помірним $(r=0,3-0,5)$, слабким $(r<0,3)$ [9]. Кількісні показники обробляли статистично. Обробку отриманих даних виконано у відділі системних статистичних досліджень Тернопільського державного медичного університету імені І. Я. Горбачевського. Різницю між порівнюваними величинами визначали за критеріями Стьюдента і Манна - Уїтні [10]. Варто вказати, що дослідження та евтаназію експериментальних тварин проводили з дотриманням Загальних етичних принципів експериментів на тваринах, ухвалених на Першому національному конгресі з біоетики (Київ, 2001), та відповідно до Європейської конвенції про захист хребетних тварин, що використовуються для дослідних та інших наукових цілей [11].

РЕЗУЛЬТАТИ Й ОБГОВОРЕННЯ. ВСТаНОВлено, що видалення 31,5 \% паренхіми печінки не призводило до суттєвих змін рівнів АТФ, АДФ та АМФ і досліджуваних морфометричних параметрів у м'язовій оболонці клубової кишки (табл. 1, 2). В експериментальних тварин через місяць після резекції 58,1 \% паренхіми печінки при розтині очеревинної порожнини спостерігали розширення ворітної печінкової вени, спле-

Таблиця 1 - Концентрація аденозинтрифоссрату, аденозиндифоссрату й аденозинмонофоосфату

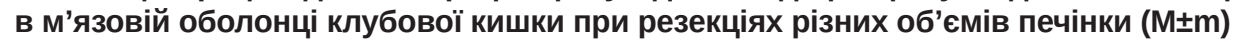

\begin{tabular}{|c|c|c|c|}
\hline \multirow{2}{*}{ Показник, мкМ/г } & \multicolumn{3}{|c|}{ Група спостереження } \\
\hline & 1-ша & 2-га & 3-тя \\
\hline ATФ & $0,780 \pm 0,006$ & $0,768 \pm 0,009$ & $0,562 \pm 0,004^{\star \star \star}$ \\
\hline АДФ & $0,450 \pm 0,003$ & $0,446 \pm 0,005$ & $0,385 \pm 0,002^{\star \star \star}$ \\
\hline AMФ & $0,380 \pm 0,003$ & $0,376 \pm 0,003$ & $0,292 \pm 0,002^{\star \star \star}$ \\
\hline
\end{tabular}

Примітка. *** - p<0,001 порівняно з 1-ю групою.

Таблиця 2 - Морфометрична характеристика м'язової оболонки клубової кишки експериментальних тварин (M $\pm m)$

\begin{tabular}{|l|c|c|c|}
\hline \multirow{2}{*}{ Показник } & \multicolumn{3}{|c|}{ Група спостереження } \\
\cline { 2 - 4 } & 1-ша & 2 -га & 3-тя \\
\hline TMO, мкм & $62,70 \pm 0,84$ & $61,80 \pm 0,81$ & $58,90 \pm 0,66^{*}$ \\
\hline BOM, \% & $88,6 \pm 0,6$ & $88,5 \pm 0,7$ & $86,6 \pm 0,6^{*}$ \\
\hline BOC, \% & $11,4 \pm 0,2$ & $11,5 \pm 0,2$ & $13,4 \pm 0,3^{*}$ \\
\hline CMB & $0,128 \pm 0,001$ & $0,130 \pm 0,003$ & $0,155 \pm 0,003^{\star \star \star}$ \\
\hline BOПM, \% & $2,10 \pm 0,02$ & $5,50 \pm 0,06^{\star \star \star}$ & $43,10 \pm 0,54^{\star \star \star}$ \\
\hline
\end{tabular}

Примітка. * - p<0,05; *** - p<0,001 порівняно з 1-ю групою. 
номегалію, повнокров'я і розширення брижових вен та видимого венозного русла тонкої і товстої кишок, асцит. Слизова оболонка клубової кишки повнокровна, набрякла, з поодинокими осередками точкових крововиливів. Описане вище свідчило про наявність пострезекційної портальної гіпертензії [3-5].

При резекції 58,1 \% паренхіми печінки суттєво змінювалася концентрація АТФ, АДФ, АМФ у м'язовій оболонці клубової кишки. Так, вміст АТФ у досліджуваній структурі за даних експериментальних умов зменшився $3(0,780 \pm 0,005)$ до $(0,562 \pm 0,004)$ мкМ/г. Між наведеними цифрровими величинами встановлено виражену статистично достовірну різницю ( $<<0,001)$. При цьому останній показник виявився нижчим за попередній на 27,9 \%. Значення АДФ у 1-й групі спостережень дорівнювало $(0,450 \pm 0,003)$ мкM/г, а через місяць після резекції 58,1 \% паренхіми печінки 3 високою статистично достовірною різницею ( $p<0,001)$ зменшилося на 16,7 \%. Через місяць після видалення 58,1 \% паренхіми печінки майже аналогічно змінювався рівень АМФ у м'язовій оболонці клубової кишки, досягаючи при цьому $(0,292 \pm 0,002)$ мкМ/г. Варто зазначити, що наведений показник за даних експериментальних умов статистично достовірно $(p<0,001)$ знизився на 23,1 \% порівняно 3 1-ю групою спостережень, в якій становив $(0,380 \pm 0,003)$ мкM/г. Отримані величини свідчать про те, що при тривалій пострезекційній портальній гіпертензії істотно погіршується енергетичне забезпечення міоцитів м'язової оболонки клубової кишки.

Наведене також підтверджувалося відношенням концентрації АТФ до концентрації АДФ. У контрольних спостереженнях воно дорівнювало 1,73, а через місяць після видалення 58,1 \% паренхіми печінки - 1,45, тобто зменшилося на 16,2 \%. Деякі дослідники коефріцієнт АТФ/АДФ вважають показником енергетичного стану клітини [12]. Погіршення енергетичного забезпечення м'язової оболонки клубової кишки за умов пострезекційної портальної гіпертензії може призводити до вираженого порушення її моторики, пошкоджень структур та дисорункції досліджуваного органа [12].

За результатами моророметричних вимірів, досліджувані кількісні морфологічні показники м'язової оболонки клубової кишки через місяць після резекції 58,1 \% паренхіми печінки суттєво змінювалися. Так, за даних експериментальних умов товщина м'язової оболонки досліджуваного органа статистично достовірно $(p<0,05)$ зменшилася на 6,1 \%. Відносний об'єм міоцитів при цьому досягав $(8,66 \pm 0,6) \%$. Цей моророметричний параметр виявився на 2,25 \% $(p<0,05)$ нижчим порівняно з аналогічним контрольним по- казником - $(88,6 \pm 0,6) \%$. Відносний об'єм строми в м'язовій оболонці клубової кишки через місяць після видалення 58,1 \% паренхіми печінки 3 вираженою статистично достовірною різницею $(p<0,001)$ зріс з $(11,4 \pm 0,2)$ до $(13,4 \pm 0,3) \%$, тобто на 17,5\%. Виражене зростання при цьому стромально-міоцитарних відношень на 21,1 \% ( $<<0,001)$ підтверджувало збільшення строми в м'язовій оболонці клубової кишки. Відносний об'єм пошкоджених міоцитів у м'язовій оболонці клубової кишки за даних експериментальних умов зріс $з(2,10 \pm 0,02)$ до $(43,10 \pm 0,54) \%$, тобто у 20,5 раза $(\mathrm{p}<0,001)$.

Під час кореляційного аналізу встановлено наявність сильних позитивних кореляційних взаємозв'язків між відносним об'ємом пошкоджених міоцитів та рівнем АТФ у м'язовій оболонці клубової кишки $(r=+0,78 \pm 0,03)$ за даних експериментальних умов. Значні позитивні взаємозв'язки виявлено між відносним об'ємом строми в м'язовій оболонці та концентрацією

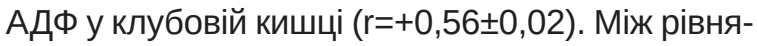
ми АДФ і АМФ та СМВ коефріцієнт парної кореляції дорівнював $+0,69 \pm 0,02$. Описані кореляційні взаємозв'язки виявлено за умов резекції 58,1 \% паренхіми печінки, а при видаленні 31,5 \% вони були значно меншими. Встановлене свідчило про наявність виражених взаємозв'язків між ступенем пошкодження досліджуваних структур та їх енергетичним забезпеченням.

Гістологічно в мікропрепаратах клубової кишки експериментальних тварин 3-ї групи спостерігали виражені судинні розлади (повнокров'я переважно венозних судин, явища перивазального набряку, стази у венозній частині мікрогемоциркуляторного русла, осередки діапедезних крововиливів), дистрофрічні, некробіотичні зміни епітеліоцитів, міоцитів, ендотеліоцитів судин, стромальних структур, інсрільтративні та склеротичні процеси. Описані патогістологічні зміни в стінці досліджуваного органа при видаленні 31,5 \% паренхіми печінки були незначними. Варто також зазначити, що виявлені патогістологічні пошкодження стінки клубової кишки при резекції печінки відповідали досліджуваним гістостереометричним параметрам.

ВИСНОВКИ. Резекція великих об'ємів паренхіми печінки призводить до розвитку пострезекційної портальної гіпертензії, суттєвого погіршення енергетичного забезпечення м'язової оболонки, пошкоджень структур оболонок та судинного русла клубової кишки. Ступінь зниження енергетичного забезпечення м'язової оболонки залежить від видаленого об'єму паренхіми печінки та вираження пошкоджень структур клубової кишки. 
Перспективи подальших досліджень. Всебічне вивчення енергетичного забезпечення м'язової оболонки клубової кишки при постре- зекційній портальній гіпертензії дозволить істотно покращити ії діагностику, корекцію та профрілактику.

\section{СПИСОК ЛІТЕРАТУРИ}

1. Вишневский В. А. Сегментарные резекции, отдаленные результаты при злокачественных опухолях печени / В. А. Вишневский, М. Г. Ефранов, И.В.Казаков // Укр. журн. хірургії. - 2012. - № 1 (16). - С. 5-15.

2. Rialon K. L. Impact of screening for hepatic hemangioma in patients with multiple cutaneous infantile hemangiomas / K. L. Rialon, R. Murillo, R. O. Fevurtly // Pediatr. Dermatol. - 2015. - 32 (6). - P. 162-167.

3. Гнатюк М. С. Морфометрична оцінка особливостей ремоделювання структур дванадцятипалої кишки при резекції різних об'ємів печінки / М. С. Гнатюк, Л. В. Татарчук, О. Б. Ясіновський // Наук. вісн. Ужгород. ун-ту. Серія "Медицина". - 2016. - Вип. 1 (53). C. 92-95.

4. Paravecino M. Major hepatic resection for hepatocellular carcinoma with or without portal vein embolization: Perioperutive outcome and survival // M. Paravecino, I. S. Chun, D. C. Madoff // Surgery. -2009. - 145, No. 4. - P. 399-405.

5. Могилевец Э. В. Портальная гипертензия, осложненная кровотечением из варикозно расширенных вен пищевода и желудка: современное состояние проблемы лечения и профилактики /Э. В. Могилевец, П. В. Горелик, О. И. Дубровщик // Укр. журн. хірургії. 2018. - № 1 (36). - С. 67-72.

\section{REFERENCES}

1.Vishnevskiy, V.A., Yefanov, M.G., \& Kazakov, I.V. (2012). Segmentarnyye rezektsyi, otdalennyye rezultaty pri zlokachestvennykh opukholyakh pecheni [Segmentar resection, long-term results in malignant liver tumors]. Ukr. Zhurnal Khirurgii - Ukrainian Journal of Surgery, 1 (16), 5-15 [in Russian].

2. Rialon, K.L. Murillo, R., \& Fevurtly, R.O. (2015). Impact of screening for hepatic hemangioma in patients with multiple cutaneous infantile hemangiomas. Pediatr. Dermatol., 32 (6), 162-167.

3. Hnatiuk, M.S., Tatarchuk, L.V., Yasinovskyi, O.B. (2016). Morfometrychna otsinka osoblyvostei remodeliuvanniia struktur dvanadtsiatypaloi kyshky pry resektsii riznykh obiemiv pechinky [Morphometric evaluation of the features of remodeling of duodenal structures during resection of different volumes of the liver]. Naukovyi visnyk Uzhhorodskoho universytetu. Seriia "Medytsyna" Scientific Journal of Uzhhorod University. Series "Medicine", 1 (49), 3-5 [in Ukrainian].

4. Paravecino, M., Chun, I.S., \& Madoff, D.C. (2009). Major hepatic resection for hepatocellular carcinoma with or without portal vein embolization: Perioperutive outcome and survival. Surgery, 145, 4, 399-405.
6. Sawada K. Multiple portal hypertensive polyps of the jejunum accompanied by anemia of the unknown origin / K. Sawada, T. Ohtake, N.Veno // Gastrointest. Endosc. - 2011. - 73. - P. 179-182.

7. Cohn W. E. The separation of adenosine polyphosphates by ion exchange and paper chromatography / W. E. Cohn, C. E. Carter // J. Amer. Chem. Soc. - 1950. No. 2. - P. 4273-4275.

8. Сорочинников А. Г. Гистологическая и микроскопическая техника / А. Г. Сорочинников, А. Е. Доросевич. - М. : Медицина, 2007. - 448 с.

9. Автандилов Г. Г. Основы количественной патологической анатомии / Г. Г. Автандилов. - М. : Медицина, 2002. - 240 с.

10. Лапач С. Н. Статистические методы в медико-биологических исследованиях Excell / С. Н. Лапач, А. В. Губенко, П. Н. Бабич. - К. : Морион, 2001. -410 с.

11. Резников О. Г. Загальні етичні принципи експериментів на тваринах / О. Г. Резников // Ендокринологія. - 2003. - 8, № 1. - С. 142-145.

12. Бенедикт В. В. Про значення процесів енергозабезпечення тонкої кишки в патогенезі її функціональної непрохідності при поширеному перитоніті і кишковій непрохідності / В. В. Бенедикт // Шпитальна хірургія. - 2010. - № 2 (50). - С. 59-62.

5. Mogilevets, E.V., Gorelyk, P.V., \& Dubrovshchik, O.I. (2018). Portalnaya gipertenziya, oslozhnennaya krovotecheniyem iz varikozno rasshyrennykh ven pishchevoda i zheludka: sovremennoye sostoyaniye problemy lecheniya i profilaktiki [Portal hypertension complicated by bleeding from varicose veins of the esophagus and the stomach: the current state of the problem of treatment and prevention]. Ukr. zhurnal khirurhiia - Ukrainian Journal of Surgery, 1 (36), 67-72 [in Russian].

6. Sawada, K., Ohtake, T., \& Veno, N. (2011). Multiple portal hypertensive polyps of the jejunum accompanied by anemia of the unknown origin. Gastrointest., Endosc., 73, 179-182.

7. Cohn, W.E., \& Carter, C.E. (1950). The separation of adenosine polyphosphates by ion exchange and paper chromatography. J. Amer. Chem. Soc., 2, 4273-4275.

8. Sorochinnikov, A.G. \& Dorosyevich, A.Ye. (2007). Gistologichieskaya i mikroskopicheskaya tekhnika [Histological and microscopic equipments]. Moscow: Meditsina [in Russian].

9. Avtadnilov, G.G. (2002). Osnovy kolichestvennoy patologicheskoy anatomii [Basis of quantitative pathological anatomy]. Moscow: Meditsina [in Russian]. 
10. Lapach, S.N., Gubenko, A.V., \& Babich, P.N. (2001). Statisticheskiye metody $v$ mediko-biologichieskikh issledovaniyakh Excell [Statistical methods in medicobiological investigation Excell]. Kyiv: Morion [in Ukrainian].

11. Reznikov, O.H. (2003). Zahalni etychni pryntsypy eksperymentiv na tvarynakh [General ethical principles of experiments on animals]. Endokrynolohiia - Endokrinology, 8, 1, 142-145 [in Ukrainian].
12. Benedykt, V.V. (2010). Pro znachennia protsesiv enerhozabezpechennia tonkoi kyshky v patohenezi yii funktsionalnoi neprokhidnosti pry poshyrenomu perytoniti i kyshkovii neprokhidnosti [On the importance of the processes of energy supply of the small intestine in the pathogenesis of its functional impedance in the widespread peritonitis and intestinal obstruction]. Shpytalna khirurhiia-Hospital Surgery, 2 (50), 59-62 [in Ukrainian].

Л. В. Татарчук, А. Г. Шульгай, М. С. Гнатюк ТЕРНОПОЛЬСКИЙ ГОСУДАРСТВЕННЫЙ МЕДИЦИНСКИЙ УНИВЕРСИТЕТ ИМЕНИ И. Я. ГОРБАЧЕВСКОГО

\section{ОСОБЕННОСТИ ЭНЕРГООБЕСПЕЧЕНИЯ МЫШЕЧНОЙ ОБОЛОЧКИ ПОДВЗДОШНОЙ КИШКИ ПРИ РЕЗЕКЦИЯХ РАЗНЫХ ОБЪЕМОВ ПЕЧЕНИ}

\section{Резюме}

Вступление. Удаление больших объемов паренхимы печени может сопровождаться возникновением пострезекционной портальной гипертензии. Последняя приводит к морфологической перестройке органов бассейна воротной печеночной вены, поражению их структур, изменениям энергетического обеспечения структур, которые при повреждениях подвздошной кишки в названных патологических условиях исследованы недостаточно.

Цель исследования - изучить особенности энергетического обеспечения мышечной оболочки подвздошной кишки при резекциях разных объемов паренхимы печени.

Методы исследования. Исследования проведены на 45 белых крысах-самцах, которых разделили на 3 группы: 1-я насчитывала 15 интактных животных; 2-я - 15 крыс, у которых было удалено 31,5 \% паренхимы печени; 3-я - 15 животных после резекции 58,1 \% паренхимы печени. Эвтаназию экспериментальных животных осуществляли путем кровопускания в условиях тиопенталового наркоза через месяц от начала опыта. Состояние энергетического обеспечения мышечной оболочки подвздошной кишки при пострезекционной портальной гипертензии изучали, определяя в ней уровни АТФ, АДФ и АМФ. Гистологические препараты подвздошной кишки красили гематоксилин-эозином, по Ван-Гизон, Маллори, Вейгерту, толуидиновым синим. Гистостереометрически определяли толщину мышечной оболочки подвздошной кишки, относительные объемы миоцитов, стромы, поврежденных миоцитов, стромально-миоцитарные отношения. Количественные показатели обрабатывали статистически.

Результаты и обсуждение. У крыс через месяц после резекции 58,1 \% паренхимы печени наблюдали расширение воротной печеночной вены, полнокровие и расширение брыжеечных вен и видимого венозного русла тонкой и толстой кишок, спленомегалию, асцит. Выявленные изменения свидетельствовали о наличии портальной гипертензии. Слизистая оболочка подвздошной кишки полнокровная, отечная, с единичными очагами точечных кровоизлияний. В стенке подвздошной кишки через месяц после резекции 58,1 \% паренхимы печени выявили дистрофию, некробиоз эпителиоцитов, миоцитов, эндотелиоцитов, стромальных структур, инфильтративные и склеротические процессы. При удалении 58,1 \% этого органа относительные объемы стромы увеличились на 17,5 \%, поврежденных миоцитов - у 20,5 раза, стромально-миоцитарные отношения - на 21,1%, что указывало на значительное поражение мышечной оболочки подвздошной кишки. При выявленном поражении подвздошной кишки выраженно в мышечной оболочке снизились уровни АТФ, АДФ, АМФ, что свидетельствовало о существенном ухудшении энергообеспечения исследуемой структуры.

Выводы. Резекция больших объемов паренхимы печени приводит к развитию пострезекционной портальной гипертензии, существенному ухудшению энергетического обеспечения мышечной оболочки, повреждениям структур оболочек и сосудистого русла подвздошной кишки. Степень снижения энергетического обеспечения мышечной оболочки зависит от удаленного объема паренхимы печени и выраженности повреждений структур подвздошной кишки.

КЛЮЧЕВЫЕ СЛОВА: резекция печени; мышечная оболочка; подвздошная кишка; энергетическое обеспечение. 


\section{FEATURES OF ENERGY SUPPLYING OF THE MUSCLE OF ILEUM AT RESECTION OF DIFFERENT VOLUMES OF LIVER}

\section{Summary}

Introduction. Removal of large volumes of liver parenchyma are complicated by postresection portal hypertension. The latter leads to the morphological rearrangement of the organs of the drainage basin portal hepatic vein, the damage to their structures, changes in the energy supply structures, which are not sufficiently investigated when damaging the ileum in the named pathological conditions.

The aim of the study - to study the features of the energy supply of the muscle of the ileum at resection of different volumes of liver parenchyma.

Research Methods. Studies were conducted on 45 white male rats, which were divided into 3 groups. The group 1 consisted of 15 intact animals, group $2-15$ rats, in which $31.5 \%$ of liver parenchyma was removed, $3-15$ rats were after resection of $58.1 \%$ of liver parenchyma. Euthanasia of experimental animals was carried out by bloodletting in conditions of thiopental anesthesia 1 month after the beginning of the experiment. The state of the energy supply of the muscle membrane of the ileum in conditions of postresection portal hypertension was studied by determining the levels of ATP, ADP and AMF in it. Histologic preparations from the ileum dyed hematoxylin-eosin, for van Gizon, Mallory, Weigert, toluidine blue. It was histostereometrically determined the thickness of the muscle of the ileum, relative volumes of myocytes, stroma, damaged myocytes, stromal-myocyte relations. Quantitative values were processed statistically.

Results and Discussion. In rats, one month after resection, $58.1 \%$ of the liver parenchyma was followed by enlargement of the hepatic portal vein, enlargement and widening of the mesentery veins and the visible venous vessels of the small and large intestines, splenomegaly, ascites. The revealed changes indicated the presence of portal hypertension. Mucous membrane of the empty bowel is full-blooded, edematous, with single cells of point hemorrhages. In the wall of the ileum, resection of $58.1 \%$ of the liver parenchyma revealed dystrophy, necrobiosis of epithelial cells, myocytes, endothelial cells, stromal structures, infiltrative and sclerotic processes. With removal of $58.1 \%$ of the volume of this organ, the relative volumes of stroma increased by $17.5 \%$, damaged myocytes by 20.5 times, stromal-myocyte relations - by $21.1 \%$, indicating significant damage to the muscle ileum. At the defeat of the ileum was detected, the levels of ATP, ADP, and AMF were expressed in the muscle, indicating a marked deterioration in the energy supply of the investigated structure.

Conclusions. Resection of large volumes of liver parenchyma leads to the development of postresection portal hypertension, marked deterioration of the energy supply of the muscular membrane, damage to the structures of the membranes and the vascular bad of the ileum. The degree of reduction of energy supply of the muscle depends on the removed volume of liver parenchyma and severity damages of the ileum structures.

KEY WORDS: liver resection; muscle; ileum; energy supply.

Отримано 18.09.18

Адреса для листування: М. С. Гнатюк, Тернопільський державний медичний університет імені І. Я. Горбачевського, майдан Волі, 1, Тернопіль, 46001, Україна, e-mail: hnatjuk@tdmu.edu.uа. 